\title{
Filiação e tecnologias de reprodução assistida: entre medicina e direito
}

\author{
| ${ }^{1}$ Luciane da Costa Moás, ${ }^{2}$ Marilena Cordeiro D. Villela Correa |
}

Resumo: O presente trabalho tem o intuito de analisar os critérios jurídicos de determinação das relações parentais, propondo a reflexão sobre a paternidade ou maternidade homossexual como manifestação do direito à vida familiar. Para tanto, discute-se o impacto das seguintes inovações biotecnológicas: por um lado, a possibilidade de concepção fora do corpo humano, que ameaça quebrar o valor simbólico que sempre assimilou a categoria de genitor àquela de pai, ameaça esta que se apresenta de forma mais marcante quando a demanda pela reprodução assistida se dá por casais de mesmo sexo. Por outro, a disponibilidade de exames genéticos que permitem o acesso à verdade biológica com alto grau de confiabilidade, provocando verdadeiro embate entre o critério biológico de determinação da paternidade e o critério sócio-afetivo.

> Palavras-chave: família, filiação, homoafetividade, reprodução, discriminação.
1 Graduação em Direito pela Universidade do Estado do Rio de Janeiro; mestrado em Direito da Cidade pela UERJ e doutorado em Saúde Coletiva pelo IMS-UERJ; professora da Universidade Federal Rural do Rio de Janeiro (UFRRJ). Endereço eletrônico: lumoas@ yahoo.com.br.

${ }^{2}$ Médica, doutora em Ciências Humanas e Saúde pela UERJ; pós-doutorado no CermesEHESS e na Escola Nacional de Saúde Pública da Fiocruz professora adjunta do IMSUERJ, vice-coordenadora da Comissão de Ética em Pesquisa da UERJ, pesquisadora colaboradora da Fiocruz e pesquisadora associada ao Cermes-EHESS. Endereço eletrônico: mcorrea@ism.com.br

Recebido em: 31/08/2009 Aprovado em: 15/03/2010. 
A família sofreu profundas mudanças de função, natureza, composição e, notadamente, de concepção, sobretudo a partir do final do século XIX e início do século XX. De natureza patriarcal, a definição das funções se dava em razão do sexo: a mulher desempenhava o papel de esposa e mãe, enquanto ao homem competia o dever de zelar pela unidade da família e seu sustento. Esse modelo de relações parentais vem cedendo lugar à chamada família eudemonista, termo empregado para identificar a família na qual se constata: o aumento do valor do envolvimento afetivo, da busca da felicidade individual que, em razão do processo de emancipação de seus membros, defasa a secular noção de que o todo (a família) deveria sobrepor-se às partes (seus integrantes).

A conformação hierárquica foi substituída por um locus mais democrático, de vivência do amor, afeto, respeito e responsabilidades (LÔBO, 2009). Para o Direito também, a finalidade instrumental da família não mais reside apenas na manutenção do nome, do patrimônio e da força de trabalho representada pelo elevado número de filhos tidos, mas na melhor realização dos interesses afetivos e existenciais de todos e de cada um. Assim, a família veio a assumir variados arranjos: além do tradicional casamento, pode apresentar-se hoje, nos formatos denominados como informal, monoparental e também homoafetiva. ${ }^{1}$

Pelo fato de a família ser uma realidade muito próxima dos indivíduos, é possível que, para o senso comum, as mudanças verificadas acarretem a sensação de que a família está diferente porque se sentiu o impacto de transformações como o movimento feminista e a emancipação das mulheres, a luta pelo divórcio, o decréscimo do número de casamentos e de filhos, e teve de se ajustar a esse processo. A sensação de que a família "está diferente" é muitas vezes associada à ideia de crise e decadência, principalmente quando se destaca a vocação família completa, que implicaria o direito à filiação, questão central nos debates sobre família, sexualidade e relações de parentesco. No que diz respeito à família homoparental completa, essa resistência é ainda maior e pode ser encontrada também no debate teórico: tanto na literatura de cunho psicanalítico, quanto em correntes das ciências sociais e humanas e mesmo no Direito.

Assim, pretende-se neste artigo abordar a filiação por indivíduos que se descrevem como homoafetivos, sem dissociar essa questão da discussão sobre critérios jurídicos de determinação da filiação. Tanto os critérios 
utilizados no passado recente quanto os que se encontram transformados contemporaneamente pelas novas tecnologias reprodutivas e genéticas (reprodução assistida e determinação genética da paternidade). Para isso, propõe-se enfocar argumentos jurídicos e sociais que asseguram o direito à vida familiar homossexual; seja através do casamento, seja através de qualquer outra forma de conjugalidade, desde que resultado de opção individual e com consentimento mútuo, decorrentes da liberdade pública fundamental de constituir família, um direito assegurado na própria Declaração Universal dos Direitos Humanos e na Constituição Federal do Brasil, representando a filiação uma possibilidade advinda deste reconhecimento.

\section{O direito à vida familiar}

No que diz respeito ao indivíduo homossexual, pode-se falar em avanços percebidos em países do mundo ocidental. Quase todas as legislaçôes proíbem a discriminação contra os homossexuais pelo comportamento em si ou pelo fato da orientação sexual; como o fazem em relação a outros atributos humanos como raça, sexo, religião, etnia, etc. Entretanto, esse reconhecimento se expressa apenas através de uma espécie de liberdade negativa, ou seja, têm direito à relação afetiva ou ao exercício da sexualidade desde que de forma discreta, restrita ao espaço privado. Assegura-se, desse modo, o direito à privacidade, mas não exatamente o direito à vida familiar.

Mas quando a questão sai da esfera privada da intimidade e ganha o espaço público das reivindicações por direitos, o avanço éainda incipiente, sendo importante observar os argumentos contrários à ampliação de direitos no espaço público. Em resumo, trata-se de argumentos que, basicamente, reforçam o modelo naturalizado de vida heterossexual e, em consequência, propugnam a proibição do casamento de casais de mesmo sexo. Se bastante frágil e sem amparo na atual doutrina jurídica, o mecanismo social de naturalização é bastante reforçado pelos avanços tecnológicos na área biomédica, rebatendo-se no discurso médico-psicólogico.

A distinção entre esfera privada e espaço público está longe de ser um preciosismo ou simples sutileza. A sociologia do Direito (FASSIN, 1998) veio nos mostrar que, embora fundamentalmente necessária à conquista de alguns direitos civis e sociais, que já se encontram garantidos em alguns contextos entre os quais os mais festejados são a utilização do mesmo nome, seguro saúde, 
aposentadoria, pensão alimentícia, divisão do patrimônio adquirido com o esforço comum -, aquela conquista não logrou conter tentativas de perenização e legitimação de preconceitos mesmo no discurso do próprio Direito e em certas correntes das ciências humanas e sociais.

Para Roudinesco (2003), por exemplo, a crescente visibilidade social do desejo de exercício da conjugalidade homossexual e seus desdobramentos como a filiação, nos exatos termos em que a conjugalidade heterossexual é exercida, seria incômoda e uma ameaça aos valores tradicionais da família, como a perda de sua função como base da sociedade. Além disso, para os adeptos desta corrente, tratarse-ia de contrassenso, por parte de homossexuais, o desejo de integração a uma instituição por eles mesmos repelida em razão de seu caráter opressor. A família responsável por um passado de perseguição estaria sendo redescoberta pelos homossexuais que, em um dado momento, passaram a desejá-la, acentuando uma (supostamente indesejável) crise, iniciada com a ruptura do modelo patriarcal.

Ao contrário, em nome da igualdade de direitos e de princípios constitucionais como a não-discriminação e a dignidade, o casamento entre pessoas de mesmo sexo como forma de constituir família deve ser compreendido como conquista, fruto de opção política que estende o direito ao casamento a todos igualmente, independentemente de sua sexualidade. Encará-lo como simples desejo de imitar a heterossexualidade não se sustenta - até porque, e o que é mais importante, nem todos os homossexuais vivem relações afetivas sólidas, estáveis, duráveis, ou desejam casar. Algumas pessoas tampouco desejam tais relações estáveis ou duráveis, independentemente de sua sexualidade e orientação sexual. O problema da discriminação se coloca quando aqueles que o desejam são impedidos pelo fato de sua orientação sexual (homossexual).

A ideia de família como um conjunto de pessoas ligadas entre si pelo casamento heterossexual, que no passado assegurava a transmissão do nome e do patrimônio, reforçando o imperativo de ordem biológica, já que a reprodução ocorria principalmente através de relações sexuais entre um homem e uma mulher, é dificilmente ultrapassada. Dentre os "argumentos científicos" da interdição do acesso à vida familiar aos homossexuais, notadamente em relação ao desejo de filhos, têm destaque os de caráter biológico. Apesar de falho, o impacto social é grande, sendo culturalmente aceita a regra natural de a procriação ocorrer apenas entre um homem e uma mulher. 
A resistência à mudança disso que estamos chamando naturalização da família

e do casamento aparece no discurso da desordem, degradação, caos, diante da pluralidade de formas de união, efetivamente encontradas atualmente nas sociedades. Para os adeptos desta posição (THERY, 1997; 2003; LEGENDRE, 2004; ROUDINESCO, 2003), o fato de a família se apresentar atualmente como monoparental, recomposta, gerada artificialmente, e mais recentemente homoparental colocaria em risco sua função simbólica e de ordenação social, repercutindo negativamente, no plano psicológico, sobre os filhos originados dessas uniões. O problema maior não seria o fato de a criança ser educada por um pai gay ou por uma mãe lésbica, mas que nossa sociedade reconheça uma filiação homossexual. Segundo aqueles autores (entre outros), para "preservar a cultura" a sociedade deve recusar instituir qualquer forma de filiação "unissexual", ou aquela que daria à criança dois pais ou duas mães, com o objetivo de evitar a desconstrução simbólica da diferença entre feminino e masculino. Segundo eles, os homossexuais teriam de assumir a finitude de seu vínculo, do laço conjugal, já que se trata de um tipo de relação que não é apta a produzir filhos.

No Direito, os argumentos utilizados para justificar a proibição ao casamento e também a filiação por homossexuais não poderiam ser justificados na ordem política, em razão da consagração do valor universal da igualdade, que alicerça a construção de uma sociedade livre, justa e solidária. Ademais, a partir da década de 1990, em inúmeros países já não se trata mais de um movimento político isolado, ou seja, uma simples reivindicação do movimento gay, dizendo respeito à inscrição da homossexualidade na sociedade (BORRILLO, 1999). Para o autor, não há fundamento jurídico vedando o casamento e a filiação homossexual que resista a análise crítica mais detida. Os juízos de valor religiosos e morais que os recusam não podem ser o fundamento da ordem jurídica que continua sendo proibitiva na maior parte dos países ocidentais, sobretudo naqueles de tradição romano-germânica, que sofreram forte influência do direito canônico. ${ }^{2}$

Se a maior parte da doutrina e da jurisprudência francesas se pronunciou contra a extensão do casamento ao casal de mesmo sexo, foi em razão de argumentos que provêm mais da ordem religiosa ou moral que de uma análise estrita da ratio jurídica. Com efeito, depois da Revolução, o casamento é considerado um contrato sui generis, laico e único. As características religiosas, morais ou simbólicas a ele atribuídas, enganosamente representam elementos residuais de seu passado canônico. Livre dessa dimensão sacramental, o casamento republicano tem uma vocação para a extensão aos casais independentemente da orientação sexual dos parceiros (BORRILLO, 1999, p. 40). 
Segundo a visão laica e civilística, o casamento não se funda nem na reprodução, nem na lei natural, nem na ordem simbólica, nem na simetria dos corpos, nem na moral, nem na tradição, nem na prática: "apesar das lamentaçōes nostálgicas dos bons e velhos tempos do casamento estável e sólido, é na instabilidade da liberdade individual, de se unir e de se separar, que o casamento encontra, hoje em dia, sua legitimidade" (BUTLER, 2003, p. 37; grifos nossos). O desmantelamento da noção tradicional de casal e o pluralismo familiar com a diversificação dos modelos de vida em comum, longe de representarem uma degradação da família são o sinal unívoco de sua democratização e do maior desenvolvimento individual de seus membros ou componentes; cumprindo, assim, funções sociais fundamentais como o não isolamento do sujeito, a criação de uma ordem para se experimentar a vida com algum sentido, diferentemente das funções patriarcais, mencionadas acima.

O plano da filiação, correlativamente ao da conjugalidade, apresenta-se mudado. No passado, existiam injustificáveis desigualdades de tratamento entre as diferentes categorias de filhos - legítimos, adotivos, ilegítimos (naturais, incestuosos, adulterinos) que somente foram abolidas com a Constituição Federal de 1988, ao estabelecer que os filhos, havidos ou não da relação de casamento, ou por adoção, terão os mesmos direitos e qualificações, sendo proibidas quaisquer designações discriminatórias relativas à filiação. Além disso, a experiência da parentalidade inclui-se na mesma perspectiva das novas funções das uniões. As modificações verificadas no Direito de Família Brasileiro tornaram possível, ainda, a aplicação da doutrina da proteção integral de crianças e adolescentes como sujeitos de direitos universalmente reconhecidos; além de especial proteção por conta da condição peculiar de pessoas em desenvolvimento (BARBOZA, 2005). E, possibilitar aos casais de mesmo sexo se tornarem pais não viola nenhum dispositivo normativo nessa esfera.

\section{Critérios determinantes da filiação e o uso de tecnologias biomédicas}

A noção de parentesco é central para as relações disciplinadas pelo Direito de Família, sendo o parentesco normalmente definido como o laço que une duas ou mais pessoas, em decorrência de uma delas descender da outra ou de ambas descenderem de genitor comum (PEREIRA, 2007). É fácil perceber que tal conceito se refere ao parentesco consanguíneo, mas o ordenamento jurídico 
reconhece ao lado deste, o parentesco civil quando criado artificialmente pela lei em virtude da vontade dos interessados, o que ocorre através do instituto da adoção e mais recentemente da reprodução assistida. ${ }^{3}$

Nesse sentido, o artigo 1.593 do Código Civil em vigor (CC-2002) incorpora a construção teórica de reconhecimento de outra origem não-sanguínea de parentesco, além da adoção, ao estabelecer: "o parentesco é natural ou civil, conforme resulte de consanguinidade ou outra origem”. Logo, atualmente, parentesco civil é gênero do qual a adoção e a reprodução assistida heteróloga ${ }^{4}$ são espécies (FACHIN, 2003), sendo inegável o surgimento de nova espécie de parentesco resultante das inovações biotecnológicas aplicadas à reprodução humana.

Seguindo a orientação Constitucional que determina a igualdade, o nascimento de uma criança por meio dos procedimentos de reprodução assistida com doação de material genético (heteróloga) faz surgir o parentesco não somente com as pessoas que lançaram mão da técnica, mas também com os demais parentes, assim como ocorre na adoção. Várias disposições normativas aplicadas à adoção poderão assim ser aplicadas à procriação heteróloga, através de interpretação extensiva ou da analogia, ${ }^{5}$ dada a identidade do fundamento de ambos: a origem não-sanguínea para o estabelecimento do parentesco.

Filiação é conceito relacional. Entretanto, nem sempre foi assim. A compreensão do sistema de filiação consagrado pelo antigo Código Civil de 1916 e mantido em grande medida pelo Código Civil atualmente em vigor, pressupõe a análise do quadro de valores que o inspirou. $O$ sistema de filiação legítima, consagrado pelo Código Civil francês de 1804 (Código Napoleônico), tem como postulado básico o prévio estabelecimento em relação à mãe (mater semper certa est). Se a mãe é uma mulher casada, presume-se que o pai da criança é o marido da mãe - pater is est quem nuptiae demonstrant (o pai é quem as justas núpcias demonstram). Quanto aos filhos ilegítimos, a sua paternidade necessita ser juridicamente estabelecida, seja através do reconhecimento voluntário, seja através de sentença judicial.

Assim, o filho nascido até 180 dias, pelo menos, depois de estabelecida convivência conjugal; e o nascido nos 300 dias subsequentes à dissolução da sociedade conjugal, por morte, separação judicial, nulidade e anulação do casamento, é presumido como tendo sido concebido na constância do casamento. Além disso, o Código de 1916 estabeleceu caber privativamente ao marido o 
direito de contestar a legitimidade dos filhos nascidos de sua mulher, em caráter excepcional, fundamentado apenas na impotência absoluta ou na impossibilidade física e fática de coabitação com a esposa. Villela (1999, p. 128) propõe interessante correlação entre o casamento e a filiação:

\begin{abstract}
Casamento, tal como o conceito se formou através de milênios na cultura judaicoromano-cristã, é uma instituição que se define por alguns elementos essenciais. Entre eles a posse sexual exclusiva ou fidelidade. $\mathrm{O}$ dever de fidelidade recíproca dos cônjuges é um atributo básico do casamento. Mas fundamental mesmo na economia do parentesco e da filiação é o dever de fidelidade da mulher. Foi com base no dever de fidelidade da mulher, e não na sua fidelidade efetiva, que se formou a regra pater is est quem nuptiae demonstrant. $\mathrm{O}$ raciocínio pode ser deduzido aproximadamente assim: se a mulher deve fidelidade ao marido, os filhos que esta gerar tem, presumivelmente, como pai o marido dela própria.
\end{abstract}

Assim, o critério nupcialista de paternidade e a noção de que casamento e procriação estavam intimamente relacionados para a produção de efeitos reconhecidos pelo ordenamento jurídico foi revogada com a abolição do antigo Código civil. Estabelecer a certeza da paternidade - evento sempre duvidoso segundo a ordem natural era o modo de continuar preservando a unidade formal da família patriarcal. A lei civil, desse modo, relegava a "verdade biológica", bem como a afetiva, a um segundo plano, prevalecendo o interesse na preservação de valores ligados à manutenção da ordem social; neste caso, no âmbito do casamento.

Os tribunais brasileiros, incorporando os reclamos e avanços da doutrina jurídica, e também em razão dos princípios introduzidos no ordenamento jurídico pela Constituição Federal de 1988, passaram a valorizar a igualdade entre todos os filhos, apontando a verdade do sangue, bem como os valores sociológicos e afetivos da filiação, como componentes importantes para a determinação jurídica da paternidade, priorizando a felicidade e realização pessoal dos filhos em detrimento das demandas patrimoniais, centro da tutela de interesses de um passado recente.

\title{
Verdade biológica ou sócio-afetiva: entre genitor e pai
}

O critério biológico de determinação da paternidade passa a ter relevância, no Brasil, a partir da década de 60, quando o Supremo Tribunal Federal ${ }^{6}$ atenua a presunção de paternidade do filho concebido na constância do casamento, ao admitir o reconhecimento do filho adulterino a matre; principalmente nas situações em que a mulher já se encontrava separada de fato do marido e convivendo com outro homem desde a época da concepção; sendo do atual 
companheiro o filho tido, e embora continuasse existindo o vínculo formal de casamento dela com o marido. Nesse caso, além de reconhecer que a paternidade jurídica não se estabelece somente por laços de sangue, confere-se à chamada posse de estado de filho ${ }^{7}$ um papel relevante.

As inovaçôes biotecnológicas acentuaram a importância do critério biológico em razão da confiabilidade dos exames de DNA desafiando, apenas em princípio, os conceitos jurídicos de pai e de filho há séculos cristalizados. Se o critério jurídico de presunção era falho, excludente e injusto, a possibilidade de estabelecer a verdade biológica por meio do teste de DNA garante 99,99\% de probabilidade de certeza. Um filho pode assim deixar de ter pai, assim como o pai vir a ter a paternidade desconstituída. Tal possibilidade acarretou mais uma vez a necessidade de se repensar os limites dos critérios de determinação de paternidade, pois o exame de DNA apenas comprova (ou não) o vínculo genético de uma pessoa com outra.

Essa discussão nos remete a importante distinção entre as figuras de genitor e de pai. $\mathrm{O}$ interesse sobre a ascendência biológica, traduzido no direito legítimo de qualquer pessoa de conhecer a sua origem, não se confunde com os laços de afeto e de solidariedade que decorrem da convivência, indicativos do verdadeiro vínculo de paternidade. Além disso, a origem genética é pertinente ao indivíduo e seu grupo familiar, logo inclui o suposto pai biológico. Como direito personalíssimo, a origem é compreendida contemporaneamente como abrangendo a tutela do que cada indivíduo possui como seu. Ademais, de acordo com a evolução da área biomédica, seria importante ainda para prevenir ou tratar doenças (transplantes, por exemplo), situando-se, portanto, na seara da saúde pública. Quanto ao estado de filiação de cada indivíduo, pode-se afirmar ser único e de natureza sócioafetiva, fundamentado na convivência familiar, compreendendo um complexo de direitos e deveres reciprocamente considerados, coincidindo na maioria das vezes, mas não necessariamente, com os laços biológicos.

Vê-se, portanto, a heterogeneidade de variáveis critérios intervenientes no estado de filiação. Por um lado, desligou-se da origem biológica e, por consequência, de sua legitimidade, para assumir dimensão mais ampla que abranja aquela e qualquer outra origem. Nesse sentido, o estado de filiação é gênero sendo espécies a filiação biológica e não biológica. Por isso, cabe questionar o entendimento de se confundir estado de filiação com origem biológica, em grande medida em virtude do fascínio enganador exercido pelos avanços científicos em torno do DNA. Não há qualquer fundamento jurídico para tal desvio hermenêutico restritivo, pois 
a Constituição estabelece exatamente o contrário, acolhendo generosamente o estado de filiação de qualquer natureza, sem primazia de um sobre o outro.

O excessivo biologismo introduzido pelas novas tecnologias nessas relações é tão indesejável quanto o falho e precário critério de presunção nupcial, tornandose necessário a busca de novos parâmetros para determinação das relações paternofiliais, que prestigiem o afeto e a função social do pai, para que aquelas relaçoos não permaneçam apenas como relações jurídicas ou biológicas.

\begin{abstract}
A filiação, seja ela biológica ou não biológica, apresenta natureza cultural, mas não exatamente natural, embora eventualmente possa haver coincidência. Há, portanto, distinção entre ser pai e ser o ascendente biológico. A busca do procriador pode não coincidir com a busca de um pai. Direito ao reconhecimento da paternidade nem de longe é o mesmo que direito à ascendência genética ou biológica. Tem direito ao reconhecimento da paternidade todo aquele, e somente aquele, a quem falte o pai juridicamente estabelecido, não sendo correto e adequado autorizar-se a desconstituição de um vínculo de paternidade assentada nos valores sócio-afetivos, para privilegiar o caráter biológico ou consanguíneo da origem genética (FACHIN, 2002).
\end{abstract}

É sobretudo, nesse contexto, que ganha maior relevância o conceito sócioafetivo da paternidade, pois, vincula-se com maior clareza à sua dimensão fática. Os laços biológicos são um dado do indivíduo, enquanto o vínculo sócio-afetivo é construído a partir da vontade de despender tempo, carinho, afeto, orientação, algo mais amplo e de natureza diferente da carga genética de cada um. O fundamento maior da paternidade desbiologizada é a disponibilidade de exercer as atribuições de pai.

\title{
Necessidade de revisão da cultura procriativa
}

Conforme já destacado, a legislação civil atual prestigiou o valor sócio-afetivo da filiação, ao reconhecer que o parentesco pode resultar de outra origem, distinta da consangüinidade. Merece destaque o caso da determinação de que o filho havido de inseminação artificial heteróloga, desde que o procedimento seja previamente autorizado pelo marido, presume-se deste, não sendo admitida posteriormente ação negatória de paternidade, invocando a origem genética, através do pedido de realização do exame de DNA. Neste último caso, a paternidade não é constituída a partir do nascimento, mas a partir da concepção e do estado gestacional. Ao contrário, se fosse admitida a possibilidade de impugnação, ficar-se-ia sempre diante de uma paternidade incerta, ameaçando o segredo profissional do médico bem como o anonimato do doador do material genético. 
A dimensão mais democrática do planejamento familiar, tornando possível a implementação de métodos contraceptivos, determinando que qualquer indivíduo pode estabelecer o momento de ter filhos, e até mesmo a quantidade, somada à possibilidade relativamente recente de reprodução dispensando-se o ato sexual, faz com que a ordem normativa pautada no sistema de presunçôes e de aparências seja modificada, tornando-se, em tese, mais inclusiva.

Cabe indagar, neste ponto, sobre mais uma questão, talvez a mais importante para nós neste texto, sobre a pertinência dos destinatários dessas regras: podem ser aplicadas aos casais de mesmo sexo ou estão dirigidas apenas aos casais heterossexuais casados ou que convivem em uniões estáveis? A resposta depende da leitura que se faz da "ordem procriativa" (IACUB, 1999): se compreendida apenas como o conjunto de normas jurídicas que organizam as formas de inscrição genealógica e de criação biológica das pessoas ou também como a possibilidade de recusar a existência de estruturas universais que predeterminariam o conteúdo do direito à filiação fundamentadas nas leis da natureza; ou se em outros discursos das ciências humanas e sociais, notadamente aqueles marcados pela concepção antropológica estruturalista sobre a diferença de sexos, limitadora do poder normativo da sociedade.

Segundo a jurista Marcela Iacub (1999), três grandes pilares estruturam o que ela denomina a "ordem procriativa", quais sejam: a liberdade de procriar pela via natural; a assimilação da categoria de genitor a aquele de pai; a equivalência das competências procriativas e das competências parentais. O segundo pilar importa na prevalência do princípio da verdade biológica (discutido no item anterior), restando necessária uma análise dos outros dois na tentativa de demonstrarmos como essa lógica procriativa é perversa e excludente para os casais de mesmo sexo.

A liberdade procriativa em sentido positivo - baseada nos três pilares indicados por Iacub (1999) - não encontra limites quando se trata de casais heterossexuais em idade fértil e que não apresentam nenhum tipo de problema quanto à prática do ato sexual para fins reprodutivos, nem problemas genéticos que possam colocar em risco a saúde da prole. Ou seja, a procriação natural reforça a ordem simbólica da diversidade biológica dos sexos para a transmissão da vida, garantindo a continuidade das futuras geraçooes, nos mesmos moldes idealizados há séculos (BUTLER, 2003; ARAN, 2005). Nessa hipótese, não há que se cogitar de eventual prejuízo para o interesse da criança que está por nascer nem das aptidões dos pais já 
que a "competência" procriativa garantiria a competência parental, sobretudo pela coincidência entre a verdade biológica e a sócio-afetiva.

Não há o mesmo tratamento no caso, por exemplo, de uma mulher que recorre à inseminação artificial heteróloga, formando um casal com outra mulher. A manipulação técnica que permite a transmissão da vida não é capaz de imitar a natureza nem de assegurar a dita ordem simbólica (por essa via naturalizada).

Quando para procriar é necessário recorrer aos meios artificiais, notadamente a procriação medicamente assistida, a liberdade procriativa é suspeita de "obstinação", de um desejo "todo poderoso", e deve-se obter uma autorização do Estado para ter acesso. Desse modo, as técnicas alternativas para produzir ou criar uma criança não estão disponíveis a todos que desejam transmitir a vida. A desigualdade das performances corporais, quer seja em nível dos indivíduos quer dos casais, poderia ter sido eficaz por recorrer as tecnologias procriativas. Ou, ao contrário, pode-se alinhar as procriaçôes artificiais com as procriações naturais de maneira a deter o caráter político e artificial da intervenção. Assim, o direito rapidamente organizou o acesso à essa tecnologia de modo a fazer crer que é um ato sexual, e não um artifício tecnológico que dá origem a criança nascida por esses processos (IACUB, 1999, p. 199).

Admitir essa tese é o mesmo que afirmar e reconhecer que a norma jurídica, ao estabelecer que o acesso à reprodução assistida é admitido apenas a casais heterossexuais, tem o poder de retirar o caráter de artificialidade da técnica, recriando ou reinventando o ato sexual fecundo, apto a procriação, que precisaria estar sempre presente na reprodução (CORRÊEA, 2001). Além disso, é importante lembrar que tais técnicas importam na manipulação de material genético e, portanto, na presença de um terceiro, o médico, que para alguns, ainda ocupa um lugar misterioso ou indefinido nos procedimentos de reprodução assistida, já que a procriação natural importaria na presença de apenas duas pessoas.

Seguindo esse modelo, é de fato difícil admitir o reconhecimento jurídico da filiação homossexual, sendo então necessário modificar os pilares nos quais está apoiada nossa cultura procriativa dominante. Apenas em um primeiro momento poderíamos imaginar que a adoção teria subvertido esse modelo, uma vez que não são poucas as decisóes judiciais que a deferiram aos casais de mesmo sexo. No entanto, uma análise mais detida destes processos demonstra que o fundamento maior da adoção por homossexuais não prestigia diretamente o casal homossexual ou o interesse deles. $\mathrm{Na}$ razão de decidir, ${ }^{8}$ os julgadores sempre fazem referência à situação da infância desvalida, da criança que merece ter um lar, uma família, ainda que homossexual. Como se existisse uma espécie de gradação: aquelas crianças que 
já não são mais adotáveis por casais heterossexuais ainda mereceriam uma chance de ter uma vida melhor, sendo adotadas por casais homossexuais.

$\mathrm{O}$ mesmo não ocorre na reprodução assistida em que a criança ainda não existe. Mantendo a coerência com o velho modelo procriativo biologizante, os adeptos da lógica da aparência consideram o desejo de um casal homossexual de ter um filho, lançando mão da inseminação heteróloga, um mero capricho. Iacub (1999) destaca o principal argumento contrário ao acesso à reprodução assistida heteróloga por casais de mesmo sexo: "as filiações alternativas não são estruturadas somente para dar uma família a uma criança ou uma criança a uma família, mas também e, sobretudo, para validar a naturalidade e bem fundada filiação biológica” (p. 203).

Tão perverso quanto o jogo de presunções mostra-se a lógica da competência procriativa forjando a competência parental, segundo a qual quem pode naturalmente procriar está habilitado a ser pai ou mãe. Não se indaga de suas condições materiais ou emocionais, da disponibilidade de afeto ou aptidão para acolher e auxiliar no desenvolvimento da criança. Para os casais heterossexuais, em idade reprodutiva e com problemas de infertilidade que recorrem à inseminação heteróloga, também não haveria problema, desde que se garantisse a semelhança física com os doadores e, nesse sentido, a competência parental estaria assegurada. O mesmo não ocorre com quem se vê impossibilitado de simular a natureza, principalmente por sua orientação sexual, como na hipótese do casal homossexual.

\section{Considerações finais}

A ordem procriativa precisa ter por fundamento princípios racionais e democráticos. Logo, os critérios naturalísticos que deram margem à criação de presunções e aparências da ordem nupcialista apresentam-se superados e não podem continuar informando a elaboração de normas jurídicas restritivas e excludentes quanto aos direitos de casais de mesmo sexo. Nesse sentido, na inseminação heteróloga realizada por casais heterossexuais ou homossexuais, a relação sexual que inexiste faz substituir-se pela manifestação da vontade e pelo sucesso da técnica utilizada (quando ele ocorre), em conformidade com o princípio constitucional da paternidade responsável, aplicável a qualquer hipótese reprodutiva (homem/mulher como estabelece o Código Civil; ou mulher/mulher, homem/homem, através da interpretação extensiva ou aplicação analógica do mesmo dispositivo legal). 
Em que pese a legislação civil atual ter considerado o planejamento familiar (PF) apenas no âmbito da família heterossexual e que tem origem no casamento, vale lembrar que a lei 9263/96 continua em vigor e, ao disciplinar o PF cita o homem e a mulher individualmente considerados, sem fazer referência ao estado de conjugalidade ou à orientação sexual. Logo, cada caso deve ser considerado segundo suas peculiaridades para que se possa indicar a possibilidade ou não da homoparentalidade. Questão nova e que demanda maior reflexão é a pertinente a quem vai realizar a análise de determinados conceitos, tais como paternidade responsável, dignidade da pessoa humana e melhor interesse da criança, já que são conceitos jurídicos vagos, podendo sempre se opor a outro princípio de mesma estatura constitucional.

O debate sobre a filiação - e seu correspondente, a parentalidade - continua de difícil e delicada abordagem, por mobilizar valores culturais sedimentados dos indivíduos, que guardam correlação com uma esfera muito particular de cada indivíduo, e inseridos em posiçōes sociais determinadas que a filiação pode afetar no sentido de preservá-las ou alterá-las positivamente ou negativamente (LOYOLA, 2005; CORRÊA; LOYOLA, 1999). Como procuramos fazer aqui, é urgente que se coloque em debate argumentos que possam sustentar novos valores em oposição à divinização da carga genética, que só reforça o modelo de família heterossexual naturalizada; novos valores capazes de inscrever o direito à filiação em moldes mais democráticos e adequados ao momento e à vida que experimentamos na atualidade.

\section{Referências}

ARÁN, Márcia. Sexualidade e Política na cultura contemporânea: as uniōes homossexuais. In: LOYOLA, M.A. (Org.). Bioética, reprodução e gênero na sociedade contemporânea. Rio de Janeiro: ABEP, 2005. p. 213-229.

BARBOZA, Heloisa Helena. A família na perspectiva do vigente Código Civil. In: LOYOLA, M.A. (Org.). Bioética, reprodução e gênero na sociedade contemporânea. Rio de Janeiro: ABEP, 2005. p. 139-154.

BORRILLO, Daniel. O casamento homossexual: homenagem da heresia à ortodoxia? In: FÈDIDA, P. e BORRILLO, D. (Org.). A sexualidade tem futuro? Rio de Janeiro: Loyola, 1999. p. 39-54.

BUTLER, Judith. Problemas de gênero: feminismo e subversão da identidade. Rio de Janeiro: Civilização Brasileira, 2003. 236 p. 
CORRÊA, Marilena Cordeiro D.V.; LOYOLA, Maria Andréa. Novas tecnologias reprodutivas: novas estratégias de reproduçao? Physis: revista de saúde coletiva, v. 9, n. 1, 1999. p. 209-234.

CORREAA, Marilena Cordeiro D.V. Novas tecnologias reprodutivas: limites da biologia ou biologia sem limites? Rio de Janeiro: EdUERJ, 2001. 263 p.

FACHIN, Luiz Edson. Paternidade e ascendência genética. In: LEITE, E. O. (Org.). Grandes temas da atualidade: o DNA como meio de prova da filiação. Rio de Janeiro: Forense, 2002. 390 p.

Direito além do novo Código Civil: novas situações sociais, filiação e família. Revista brasileira de direito de família. Porto Alegre, v. 5, n. 17, p. 101-121, abr/maio, 2003.

FASSIN, Eric. L'illusion anthropologique: homossexualite et filiation. Famille, nouvelles unions, bonher prive et cohesion sociale. Revue Bimestrielle publiée par les Editions Balland, mai/juin, 1998.

FERREIRA, Lucia Maria T. A desconstituição da paternidade no direito brasileiro. 2000. 230 p. Dissertação (Mestrado em Direito Civil) - Faculdade de Direito, Universidade do Estado do Rio de Janeiro, Rio de Janeiro, 2000.

IACUB, Marcela. Homoparentalité et ordre procréatif. BORRILLO, Daniel; FASSIN, Eric.In: . Au-delà du PaCS: L'expertise familiale à l'epreuve de l'homossexuaité. Paris: Presses Universitaires de France, 1999. 280 p.

LEGENDRE, Pierre. Poder genealógico do Estado. In: ALTOÉ, Sonia (Org.). Sujeito do direito, sujeito do desejo: direito e psicanálise. Rio de Janeiro: Revinter, 2004. p. 79-87.

LÔBO, Paulo. Direito ao Estado de filiação e direito à origem genética: uma distinção necessária. Revista brasileira de direito de família. Porto Alegre, v. 5, n.19, ago/set 2003. p. 124- 154.

. Famílias. São Paulo: Saraiva, 2009. 411p.

LOYOLA, M.A. (Org.). Bioética, reprodução e gênero na sociedade contemporânea. Rio de Janeiro: ABEP, 2005.

MOÁS, Luciane da Costa. O reconhecimento jurídico da família homoafetiva: uma questão de justiça. 2006. 295 p. Tese (Doutorado em Saúde Coletiva) - Instituto de Medicina Social, Universidade do Estado do Rio de Janeiro, Rio de Janeiro, 2006.

NADER, Paulo. Introdução ao estudo do Direito. Rio de Janeiro: Forense, 2005. 436 p.

PEREIRA, Caio Mario da S. Instituiçôes de Direito Civil. Rio de Janeiro: Forense, 2007. 585 p.

ROUDINESCO, Elisabeth. A família em desordem. Rio de Janeiro: Jorge Zahar, 2003. 267 p.

THÉRY, Irene. Le CUS en question. Esprit, out. 1997.

THÉRY, Irene. Non au mariage bis des concubins! Entrevista a Jacqueline Remy. 23 dez. 2003.

VILLELA, João Baptista. O modelo constitucional de filiação: verdades e superstiçôes. Revista brasileira de direito de família. Porto Alegre, v. 1, n. 2, jul/set, 1999. p. 139-157. 
${ }^{1}$ A Constituição Federal de 1988, ao reconhecer novas modalidades de constituição de família ao lado do casamento, trouxe a importante noção de pluralismo das relações familiares. Família informal é aquela em que, apesar da existência de direitos e deveres entre os companheiros, prescindem do vínculo formal do casamento. A modalidade monoparental é aquela formada por qualquer dos pais e seus descendentes. O termo família homoafetiva vem sendo utilizado para marcar a ideia de que a convivência entre pessoas de mesmo sexo dá origem à entidade familiar com importantes direitos reconhecidos como: alimentos, sucessões etc.

${ }^{2}$ Para os canonistas, o vínculo do casamento era indissolúvel. Implicitamente preocupados com eventual divisão de patrimônio e explicitamente preocupados com o interesse dos filhos, opuseram-se ao divórcio. Além disso, o casamento não representava para eles um mero acordo de vontades - como hoje, um contrato - mas também um sacramento. Nesse sentido, os homens não poderiam dissolver uma união realizada por Deus. Advém dos textos religiosos a ideia de que marido e mulher constituem um só corpo ou uma só carne e as relações de família influenciadas pelos dogmas da Igreja, sendo o casamento religioso o único legitimamente reconhecido, por longo período histórico.

${ }^{3}$ Vale lembrar que a afinidade não é parentesco, consistindo na relação existente entre um dos cônjuges e os parentes do outro (vínculo de menor intensidade que o parentesco e se estabelece entre sogro e genro, cunhados, madrasta e enteados etc.) Da mesma forma, marido e mulher não são parentes, $o$ que os une é o vínculo jurídico do casamento.

${ }^{4}$ Há duas modalidades de reprodução humana assistida: inseminação artificial com fecundação dentro do corpo da mulher e fertilização do embrião in vitro. Ambas podem ser homólogas, caso o material genético (óvulo e espermatozóide), seja do próprio casal que lança mão das técnicas; ou heterólogas, quando há algum tipo ordem de doação de material genético.

${ }^{5}$ Analogia é um recurso técnico que consiste em se aplicar, a uma hipótese não prevista pelo legislador, a solução por ele apresentada para uma outra hipótese fundamentalmente semelhante não prevista. Trata-se de trabalho de investigação para suprir lacunas, preenchendo as omissões legislativas. $\mathrm{Na}$ interpretação extensiva o caso está previsto em lei, mas com insuficiência verbal, sendo necessário ajuste (NADER, 2009).

${ }^{6}$ Somente após a evolução jurisprudencial surge a Lei no $7250 / 84$, disciplinando o reconhecimento do filho havido fora do matrimônio pelo cônjuge separado de fato há mais de cinco anos e, finalmente, com o advento da Constituição Federal de 1988, estabelecendo a igualdade entre todos os filhos, o critério nupcialista cede espaço ao critério biológico.

${ }^{7}$ Segundo Lobo (2004), a posse do estado de filiação constitui-se quando alguém assume o papel de filho em face daquele ou daqueles que assumem os papéis ou lugares de pai ou mãe ou pais, tendo ou não entre si vínculos biológicos. A posse de estado é a exteriorização da convivência familiar e da afetividade. Trata-se de conferir à aparência os efeitos da verossimilhança, que o direito considera satisfatória. A posse do estado de filiação era admitida apenas para fins de prova e suprimento do registro civil, se os pais convivessem em família constituída pelo casamento, ou seja, para a filiação considerada legítima. Em virtude do art. 226 da Constituição Federal, outras entidades familiares, como a união estável e a família monoparental, podem servir de fundamento para a posse do estado de filiação.

${ }^{8}$ Seção da decisão judicial (ou sentença) na qual se encontra a fundamentação e a explicação dos julgadores de por que decidiram em um sentido e não em outro. 


\section{Filiation and usage of assisted reproductive technologies: between medicine and law}

The present work aims to analyze the juridical criteria for determining the paternal-filial relations, proposing a reflection about homosexual paternity or maternity as a natural consequence of the right to family life. Along these lines, it is necessary to analyze the current discussion on the impact of biotechnological innovations on important issues, such as: the possibility of conception outside the human body, threatening to crush the symbolic value that has always assimilated the category of genitor to that of father, markedly when the demand for assisted reproduction is made by couples of the same sex; the availability of genetic exams that allow access to the biological truth with high level of trustworthiness, causing a real clash between the biological and the socialaffective criteria for determination of paternity.

> Key words: family, filiation, homoaffectivity, reproduction, discrimination. 